\title{
Mining for Color: New Blues, Yellows, and Translucent Paint
}

\author{
Barbara H. Berrie \\ National Gallery of Art \\ b-berrie@nga.gov
}

\begin{abstract}
In the sixteenth century, the Erzgebirge mountains were mined for mineral ores of cobalt and antimony that were used to make the blue pigment smalt, a potash glass, and yellow pigments based on lead-antimony oxides, respectively. By the beginning of the seventeenth century, these pigments had found a permanent place on the easel painter's palette, smalt used in place of ultramarine and the antimonial compounds enlivening the yellows of the spectrum. Mining efforts also located sources for naphtha, and improvements in distillation would have allowed it (and other solvents) to be fractioned and purified for use as a solvent and diluent for oil paint. The mention of naphtha in treatises and color-sellers' inventories attests to its use in color making. Thinning paint allowed artists to use glazes of paint to lively, luminous, coloristic effect and made blending easier. These three discoveries contributed to the saturated colors characteristic of seventeenth-century painting and offered artists latitude in the ways they pursued their goal of imitative painting.
\end{abstract}

\section{Keywords}

smalt - antimony - Naples yellow - naphtha - lead-tin-antimony yellow - painting - cobalt

* National Gallery of Art 2000B South Club Drive, Landover, MD 20785, USA. The author is grateful to the authors in this volume who provided useful comments and especially wishes to thank the editorial team: Sven Dupré, Sachiko Kusukawa, Karin Leonhard, Nicholas Forshaw and Kristyna Comer. Claudio Seccaroni, Heike Stege and Elena Basso generously read the paper and offered much appreciated advice. Many thanks to Darren J. Barker and Jeffrey Post for help with obtaining illustrations. 


\section{Introduction}

In their search for mimesis, artists combined technical prowess with a keen sensitivity to hue and light, engaging acute powers of observation to discern the colors of shadows thrown on diverse surfaces, the difference between the luster of velvet and taffeta, or the quality of a gleam of light reflected from a mirror or from armor. The ability to paint such subtle differences in appearance was admired by many sixteenth- and seventeenth-century writers, who were not only critics but also described painting materials. Such writers included Gian Paolo Lomazzo (1538-1592), the Tuscans Giorgio Vasari (1511-1574) and Raffaello Borghini (1537-1588), and the Huguenot physician, Théodore Turquet de Mayerne (1573-1654/5). ${ }^{1}$ A heightened sensitivity to color was present in society in general. Attention to color was important not only in art, but as Valentina Pugliano describes in this volume, was a crucial part of identification and characterization for the scientific and medical disciplines and other areas of erudition. ${ }^{2}$

Painters worked within this world of color using a wide array of materials. At the turn of the sixteenth century, new sources of raw materials and production led to the manufacture of vast amounts of blue and yellow pigments that augmented their palette. Such addition of colors followed the mining discoveries that occurred in present-day Germany, Austria and Hungary. These contributed to the world of color-making, providing new materials for glass-making, ceramic decoration and painters' pigments. Full exploitation of the potential of the oil medium to give impasted paint or translucent glazes was aided by production of solvents and diluents which became more available due to improvements in distillation of natural resins and increased mining for petroleum. Concurrent developments of theories of color liberated practice to be the artists' guide and influence their ways of working. ${ }^{3}$ In this chapter I will focus on cobalt, antimony and naphtha as three case studies that illustrate the impact that mining and technological discoveries had on painters' materials and methods.

1 De Mayerne's keen interest in and investigation of the physical and color properties of pigments is discussed by Leonhard in this volume. Vasari described how to make art, but in his Lives also noted individuals' techniques, style and ability to paint varieties of color and realism: he praised Sebastiano del Piombo's portrait of Pietro Aretino: "Besides being a good likeness [...] the real beard could not be more natural." Giorgio Vasari, Lives of the Most Eminent Painters, Sculptors and Architects, trans. Gaston Du C. de Vere (London, 1913), 180.

2 See Valentina Pugliano in this volume.

3 Moshe Barasch, Light and Color in the Italian Renaissance Theory of Art (New York, 1978). 


\section{The Materiality of Color}

Written descriptions of artists' materials and practice give only parts of the picture. Sources may include colors and prices, but are often imprecise in terminology and silent on the manner of use. ${ }^{4}$ Inventories of color-sellers stores are helpful in judging the range available at a specific time and place but only seldom identify who used the supplies or how they were employed. ${ }^{5}$ Treatises written for painters describe the core palette, and often include some information on how to prepare supports and use pigments, but often they only allude to practice and technique. Trade accounts and bills of lading attest to the worldwide trade in precious materials for art-making, such as colors and resins that were imported from afar, but the local, the quotidian and the secret are more difficult to learn about, though equally important. ${ }^{6}$ Although the guild structure would appear to have inhibited artistic exploration through regulations and requirements for workshop output, even the strictest rules did not, in the end, inhibit the use of novel materials. ${ }^{7}$ Personal style and individuality flourished and paved a path for others to follow and actual practice demonstrated by close observation and chemical analysis - was diverse and

4 Bomford et al., Art in the Making (London, 2006); Jo Kirby, "The Price of Quality: Factors Influencing the Cost of Pigments During the Renaissance," in Revaluing Renaissance Art, eds. Gabriele Neher and Rupert Shepherd (Aldershot, 2000), 2-40; Michelle O'Malley, Painting under Pressure: Fame, Reputation and Demand in Renaissance Florence (New Haven, 2012).

5 Louisa C. Matthew, “Vendecolori a Venezia': The Reconstruction of a Profession," The Burlington Magazine, 144 (2002), 680-6; Julia DeLancey, "Dragonsblood and Ultramarine: the Apothecary and Artists' Pigments in Renaissance Florence," in The Art Market in Italy (15th17th Centuries), eds. Louisa C. Matthew and Sara F. Matthews-Grieco (Modena, 2003), 141-50; Roland Krischel, "Zur Geschichte des venezianischen Pigmenthandels. Das Sortiment des Jacobus de Benedictis à Coloribus," Wallraf-Richartz-Jahrbuch, 63 (2002), 93-158; Paolo Bensi, "Gli arnesi dell'arte. I Gesuati di San Giusto alle mura e la pittura del Rinascimento a Firenze," Studi di Storia delle arti, 3 (1980), 33-47.

6 Trade in Artists' Materials. Markets and Commerce in Europe to 1700, eds. Jo Kirby, Susie Nash and Joanna Cannon (London, 2010).

7 For examples of the rules imposed by artists' guilds on use of materials see Rachel Billinge et al., "Methods and Materials of Northern European Painting in the National Gallery, 1400-1550," National Gallery Technical Bulletin, 18 (1997), 6-55; Melissa R. Katz, "Architectural Polychromy and the Painters' Trade in Medieval Spain," Gesta, 41 (2002), 3-13; Jo Kirby, David Saunders and Marika Spring. "Proscribed Pigments in Northern European Renaissance Paintings and the Case of Paris Red," Studies in Conservation, 51 (2006), 236-43. 
even idiosyncratic. ${ }^{8}$ The ways paint and color were handled showed even greater variety. Oil painting allowed colors to be mixed on the canvas and blended while wet, so artists could use gentle gradations in tone to create chiaroscuro and the effect of sfumato. Translucent paints could be prepared, and colors adjusted using thin glazes or 'veils' of color to build rich tones and subtle shading. In the sixteenth century, artists explored and exploited the full potential for creating color and texture through the use of different pigments and brushwork, employing impasted strokes and scumbles of opaque color in addition to glazes. ${ }^{9}$ Even the most adventurous artists were, however, limited by what was available to them. Thus our knowledge of trade in materials, practice and innovation in color-making provides an underlying context for the interpretation of novelty in painting practice.

Almost all of the materials used for painting, whether natural or synthetic, required some kind of processing from the raw state; methods for preparing certain colorants involved many steps, which cumulatively contributed to their cost. The rarity and expense of some meant that the production of certain colors was limited in scale and their use was restricted to special decorative purposes. Some were employed for medicines and luxury items such as perfumes and cosmetics, while others could only be differentiated from painters' colors based on the scale of production and in particular the purity of the product. $^{10}$

Newly developed means of sourcing minerals provided abundant supplies of certain elements necessary to the color-making process. Mining and the production of particular metals in combination with technological advances in manufacturing opened opportunities to add new colorants and thereby improved paint-making. Two pigments, smalt and Naples yellow, coming to painters via the ceramic and glass industries, became established on oil

8 Marika Spring, Rachel Grout and Raymond White, "Black Earths': A Study of Unusual Black and Dark Grey Pigments Used by Artists in the Sixteenth Century," National Gallery Technical Bulletin, 24 (2003), 96-114; Barbara H. Berrie, "Rethinking the History of Artists' Pigments through Chemical Analysis," Annual Review of Analytical Chemistry, 5 (2012), 441-59.

9 Jill Dunkerton, Susan Foister and Nicholas Penny, Dürer to Veronese: Sixteenth-Century Painting in the National Gallery (New Haven, 1999); Jill Dunkerton et al., Giotto to Dürer: Early Renaissance Painting in the National Gallery (New Haven, 1994); Arie Wallert and Carlo van Oosterhout, From Tempera to Oil Paint: Changes in Venetian Painting 1460-156o (Amsterdam, 1998).

10 The considerable overlap of painting and make-up in terms of color and material is discussed in this volume by Romana Sammern, who points out the common sources for information on material aspects of maquillage. 
painters' palettes in the mid-sixteenth century. Smalt is a potassium-containing (potash) glass that is colored deep blue owing to the presence of cobalt. Naples yellow, an oxide of lead and antimony, is a warm, rich, quite stable and rather intense yellow. A very different material, mineral oil (or naphtha) was mined from sources that were found in the sixteenth century. ${ }^{11}$ Using it as a diluent allowed artists to spread paint thinly, to use the translucency of oil paints to make gradations in hue to blend thinner glazes of paint, and make clear varnishes. The relationship between availability of new ores and the look of paintings solicits further investigation.

\section{Blue Colors}

From early times mineral pigments offered a variety of blue colors to painters; of these azurite and ultramarine dominated the early modern artists' palettes. ${ }^{12}$ Ultramarine provided a deep true blue, often with a violet undertone that was much admired. Lapis lazuli, the stone from which ultramarine was prepared, was transported from Badakhshan (today Afghanistan) to Constantinople (Istanbul, Turkey) and Persia, from where we can trace its exportation to the great trade centers of Venice, Genoa and Antwerp. The stone was worked up through a laborious system of grinding, washing and levigating that involved forming pastes using resins and waxes that contributed to its high cost. ${ }^{13}$ The scale of manuscript illumination offered an ideal medium for using luxury materials and miniaturists in far-flung parts of Europe had used ultramarine for a very long time. ${ }^{14}$ However its discovery in eighth-century frescoes was less expected. ${ }^{15}$ In medieval painting its use flourished and contributed to the glory of works commissioned for religious institutions. The cost of ultramarine restricted its lavish use to high value commissions, and often artists would use it only

11 Luciano Novelli and Mattia Sella, Petrolio: una storia antica (Milan, 2009).

12 The dye indigo provided another blue that was used frequently. The blue palette was completed by other minerals and less intensely colored organic blues.

Alessio Piemontese described the process in his Secreti (Venice, 1555). See Joyce Plesters, "Ultramarine," in Artists' Pigments: A Handbook of their Characteristics, ed. Ashok Roy (Washington, D.C. and Cambridge, 1986; reprinted 2012), 2: 37-65. Spike Bucklow, The Alchemy of Paint (London, 2009), 5-66.

Mark Clarke, "Anglo-Saxon Manuscript Pigments," Studies in Conservation, 49 (2004), 231-44.

15 Maria Carolina Gaetani, Ulderico Santamaria, and Claudio Seccaroni, "The Use of Egyptian Blue and Lapis Lazuli in the Middle Ages: The Wall Paintings of the San Saba Church in Rome," Studies in Conservation, 49 (2004), 13-22. 
as a final layer of color over the mineral azurite. ${ }^{16}$ The major sources of azurite in Europe were present-day Germany, Hungary, Austria and Central Europe. The Fugger family (among others) obtained azurite from the mid-140os on, in association with mining for copper and silver, enjoying a robust international trade. It seems they may have protected their local monopoly in blue by restricting the importation of ultramarine from Venice. ${ }^{17}$ While a subtle range of blues could be achieved by controlling the particle size of azurite, its green undertone was not always desired; this was adjusted however by mixing in red lakes and, as noted, applying layers of ultramarine on top.

The situation changed in the early 1500 s with the invention (or more correctly, the re-invention) of smalt. Just when silver mines were becoming more difficult to exploit and less profitable, further economic pressure came as vast quantities of silver were discovered in the New World and imported into Europe, especially through Spain. Canny mine operators and owners therefore began to exploit their mines for rarer metal ores and minerals that could be used by the color industry. The Erzgebirge (Ore Mountains) contains a large variety of such minerals. Relatively minor deposits of certain blue and purplish-blue minerals were found in the Tyrolean mountains, including blue john (a form of fluorite, calcium fluoride) and vivianite (iron phosphate). These minerals have been discovered in paintings, and no doubt others were also used especially when local sources were available. ${ }^{18}$ Oltrogge in this volume notes that Agricola specifically comments on painters using fluorite, since it did not have any other important uses. ${ }^{19}$ The use of fluorite and other

16 For a 1583 panel painting, more than twenty percent of the total cost (excluding the wood) was for blue pigments alone: see Susanne Kubersky-Piredda, “The Market for Painters' Materials in Renaissance Florence," in Trade in Artists' Materials: Markets and Commerce in Europe to 1700, eds. Jo Kirby, Susie Nash and Joanna Cannon (London, 2010), 223-43; 228; 231. Jo Kirby, "The Price of Quality: Factors Influencing the Cost of Pigments During the Renaissance," in Revaluing Renaissance Art, eds. Gabriele Neher and Rupert Shepherd (Aldershot, 2000), 2-40.

17 Andreas Burmester and Christof Kreckel, "The Relationship between Albrecht Dürer's Palette and Fifteenth/Sixteenth-century Pharmacy Price Lists: the Use of Azurite \& Ultramarine," in Painting Techniques: History, Materials and Studio Practice, eds. Ashok Roy and Perry Smith (London, 1998), 101-5.

18 Mark Richter, Oliver Hahn and Robert Fuchs, "Purple Fluorite: A Little Known Pigment and Its Use in Late Gothic and Early Renaissance Painting in Northern Europe," Studies in Conservation, 46 (2001), 1-13. Marika Spring, "Occurrences of the Purple Pigment Fluorite on paintings in the National Gallery," National Gallery Technical Bulletin, 21 (2000), 20-7. Marika Spring, "Pigments in sixteenth-century painting of the German School," in The Pictorial Technique of Grünewald and his Peers, eds. P. Béguerie-De Paepe and Michel Menu, Musée d' Unterlinden (Paris, 2007), 136-44. 
uncommon minerals for pigments seems to have been confined to regions near to these minerals' sources, suggesting they were not widely traded. ${ }^{20}$ The history of these minerals as pigments is quite scant compared to that of smalt, which became widely used.

\section{Cobalt Mining and Smalt}

Cobalt has been used for millennia to make blue glass. ${ }^{21}$ The substance has a long history of use in enamels and pottery glazes. ${ }^{22}$ These all have qualitatively the same chemical composition as the pigment smalt. As a painter's pigment cobalt was introduced at first in small amounts and to a limited extent. ${ }^{23}$ Stege has traced the first examples of cobalt in pigments in European paintings. ${ }^{24}$ These are not associated with Venice and its glass industry; the pigment has been found only infrequently in paintings from before 1450, and only identified in somewhat isolated examples, such as a painting by an anonymous Swabian master and works by the Northern artists Lukas Moser (ca. 1390-ca. 1434) and Dieric Bouts (ca. 1415-1475). From then the pigment seems to have had a gradual introduction until the mid-1550s when it is found in paintings all over Europe. ${ }^{25}$

20 From current research it appears for the most part to be restricted to German and Austrian paintings and, to our knowledge, mainly between the years 1450-1535. Fluorite was found in works painted by Lucas Cranach while he was in Austria, but it does not appear that the colorant was traded very widely; for example, there is no evidence that it was sold at fairs in Leipzig. See Gunnar Heydenreich, "The Leipzig Trade Fairs as a Market for Painters' Materials in the Sixteenth Century," in Trade in Artists Materials (2010), 297-313. Venetian blue glass changes composition in the fifteenth century, and the impurities indicate that German ore was used from then on, see Marco Verità, "Influence of the Islamic Tradition on the Chemistry and Technology of Venetian Glass," in Venice and the Islamic World 828-1797, exhibition catalogue, ed. Stefano Carboni (New York, Paris, 2007), 276-99. See also Bernard Gratuze et al., "De l'origine du cobalt: du verre à la céramique," Revue d'archéométrie, 20 (1996), 77-94.

See for example, Isabelle Biron and Sébastien Beauchoux, "Ion Beam Analysis of Mosan Enamels," Measurement Science and Technology, 14 (2003), 1564-78.

23 An intriguing suggestion that the glass was used as a pigment is mentioned by Johann Beckmann, A History of Inventions, Discoveries and Origins, trans. William Johnston, eds. William Francis and J.W. Griffith (London, 1846), 473: "There is also another receipt which orders blue-bottles to be pounded in a mortar."

24 Heike Stege, "Out of the Blue? Considerations on the Early Use of Smalt as Blue Pigment in European Easel Painting," Zeitschrift für Kunsttechnologie und Konservierung, 18 (2004), 121-42.

Bruno Mühlethaler and Jean Thissen, "Smalt," in Artists' Pigments: A Handbook of their 
The pigment, whether used for easel painting, decorating ceramics or coloring glass, was not prepared directly from the ore but from an intermediate product generally known as zaffre. In Italian sources this product is cited under variants of names such as zafera, zaffera or zafra and chafarone. ${ }^{26}$ To make zaffre, cobalt ores, which in the Erzgebirge are predominantly cobalt-nickelbismuth arsenides, were roasted (Fig. 1). ${ }^{27}$ Volatile components in the ore, particularly arsenic or zinc, might be burnt off to varying degrees depending on the temperatures used in the process. While this product was sold under the name zaffre, the roasted ore was also mixed with sand and a flux, usually one containing potassium (pearl ash or potash) obtained from lees or tartar, to make a fusible mass which was also known as zaffre. Vannoccio Biringuccio (1480-ca. 1539) described zaffre as among the "semiminerals" or "half metals" due to its reaction to heat and the difficulty of extracting a metal from it. ${ }^{28}$ Smalts in general were described by Leonardo Fioravanti (1517-1583) as "mezzo minerali" (half minerals). ${ }^{29}$ This zaffre was used to color glass, enamels and to make smalt. Glass needs only $0.1-2 \%$ cobalt to be decidedly blue, but on grind-

Characteristics, ed. Ashok Roy (Washington, D.C. and Cambridge, 1986; reprinted 2012), 2: 113-30.

26 The earliest reference to the name we know is $c ̧[z]$ afarone by the late fourteenth-century glassmaker Antonio da Pisa, see Ulrich Middeldorf, "Li tre libri dell'arte del vasaio by Cipriano Piccolpasso; Giovanni Conti; Il trattato di Antonio da Pisa sulla fabbricazione delle vetrate artistiche (secolo XIv) by Salvatore Pezzella," The Art Bulletin, 59 (1977), 42930. Among the early allusions to making smalt from zaffre is in a late fifteenth century compilation of methodologies and recipes which mentions "Florentine azure of zaffano." See W.J. Wilson, "An Alchemical Manuscript by Arnaldus De Bruxella," Osiris, 2 (1936), 220-405; 239.

27 Richard Beck, The Nature of Ore Deposits, trans. and rev. Walter H. Weed (New York and London, 1905) 2: 342-346, 2: 373. The ore minerals include erythrite, cobaltite, smaltite, skutterudite and many others.

28 Mühlethaler and Thissen, "Smalt," 114. Biringuccio said that zaffre melted with fire "in the company of vitreous things" but noted that other semi-minerals were "much more adapted for adorning paintings than anything else." The Pirotechnia of Vannoccio Biringuccio. The Classic Sixteenth Century Treatise on Metals and Metallurgy, trans. and eds. Cyril Stanley Smith and Martha Teach Gnudi (Mineola, 1990), 77; 113.

29 Leonardo Fioravanti, Dello specchio di scientia universale (Venice, 1629; 1st edition Venice, 1564), 67-8: "I mezzo minerali son gli smalti d'ogni colore [...] ma I mezi minerali non si possono metter in opra se non a guazzo, o a tempra, perche l'oglio li fa morire." This is an early instance of noting the discoloration of smalt in oil. I am grateful to Michel Hochmann for bringing this reference to my attention. These smalti do not appear to be mentioned in either the 1564,1583 or 1603 editions. 


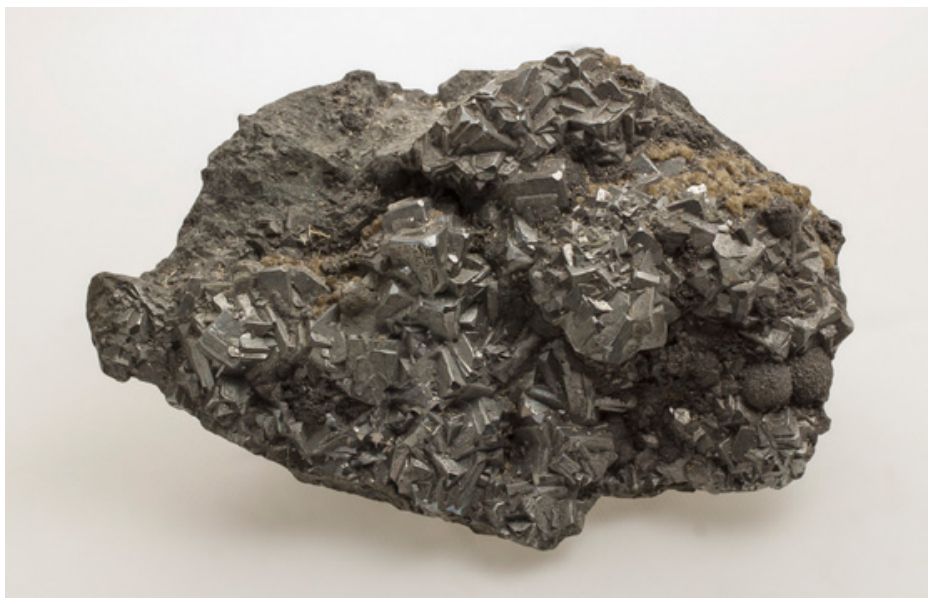

FIGURE 1 A specimen of the cobalt ore skutterudite found at Schneeberg, Germany. COURTESY OF THE SMITHSONIAN INSTITUTION, 140235 J.J. TREWLANEY COLLECTION, PHOTOGRAPHED BY KEN LARSEN.

ing the intensity of the color is lost, therefore to have an intense color, enamel and the painters' pigments would contain as much as twenty percent cobalt.

Anecdotal evidence suggests that around 1520 there was a change in the manufacture of zaffre. Later writers credit either one Peter Weidehammer or a glass-maker, Christoph Schürer, with some innovation. ${ }^{30}$ These men perhaps fused the roasted ore with sand and flux - a method that caused the production of smalt to be dramatically increased. ${ }^{31}$ The story of Weidehammer

30 Christian Melzer, Historia Schneebergensis Renovata (Schneeberg, 1714), 683. Melzer (first published in 1684) reported that Weidehammer prepared his color "aus denen Wismuth Graupen." If this is true, it may suggest that the cobalt he used was a by-product of bismuth production. Bismuth was quite commonly used in art and artifacts from the fourteenth century on, particularly in Germany. See Stefanie Küthe, Wismutkästchen - Bismut als Farbmittel (Dipl., Munich, 2004), accessed January 31, 2015, <http://www.rkk.ar.tum. de/fileadmin/wooble/www/media_rkk/downloads/Diplomarbeiten/Kuethe_Wismuth kaestchen_Dipl-2004.pdf $>$ Renate Gold, "Reconstruction and Analysis of Bismuth Painting," in Painted Wood: History and Conservation, 3 (Washington, D.C., 1998), 166-178.

Albrecht Kirsche suggests that the invention was already known, but Weidenhammer introduced the method for making the color: Albrecht Kirsche, Zisterzienser, Glasmacher und Drechsler: Glashütten in Erzgebirge und Vogtland und ihr Einfluss auf die Seiffener Holzkunst (Münster, 2005), 117. It seems unlikely to be a coincidence that 1520 is also around the time when assaying methods for measuring the metal content of ores and smelted products are developed and codified, see Christoph Bartels, "The Production of Silver, Copper and Lead in the Harz Mountains From Late Medieval Times to the Onset of 
becoming rich from the export of great quantities of zaffre to Venice was retold many times. ${ }^{32}$ And indeed, the item called "zafara" appears in a rather large amount on the 1534 inventory of the stores of a Venetian color-seller. ${ }^{33}$ Schürer, a glassmaker at Platten, obtained "cobalt" at Schneeberg, and serendipitously discovered he could use it to make a blue frit. ${ }^{34}$ He prepared this frit specifically for potters, but eventually the invention was taken to Neudeck and Holland where since "painting on glass was then much cultivated in the latter, the artists knew better how to appreciate this invention." 35

Evidence for a change in cobalt blue production comes from the analyses of ceramics. The trace metal profile in the blue glazes on della Robbia sculptures and enamel glazes in pottery corroborates the anectodal evidence for a change in the source or in the technology for making the cobalt-containing colorant. After 1520, the date given in anecdotal evidence, the minor or trace metals in the blue glaze in sculptures from the della Robbia workshop in Florence include nickel, arsenic and bismuth, which is consistent with use of raw material from veins of ore located near Schneeberg, Germany. Although it is likely that this had been the source prior to that time as well, the amounts of nickel and arsenic impurities did increase. ${ }^{36}$ Analogous trends in the levels of impurities have been observed in Italian maiolica, in which arsenic was rarely detected in pieces made before the sixteenth century but is measurably present after then. ${ }^{37}$ Zucchiatti et al. propose that the change in composition was due to a change in the technology for production of the raw material, perhaps the processes of sorting the mineral ores, namely choosing those highest in cobalt, or a change in the way they were roasted. ${ }^{38}$ Analysis of Spanish ceramic ware also indicates there was a change in composition at this time, suggesting the source

Industrialization," in Materials and Expertise in Early Modern Europe, eds. Ursula Klein and E.C. Spary (Chicago, 2010), 71-100, 89. For example, Carl Limmer, Urkundliche-pragmatisch-allgemeine Geschichte der neu-sächsischen Lande (Grimma, 1848), 83.

L.C. Matthew, "'Vendecolori' a Venezia': The Reconstruction of a Profession," The Burlington Magazine, 144 (2002), 680-6.

34 Beckmann quoted an earlier commentator, J.F. Klotzsch, in declaring this.

35 Beckmann, A History of Inventions, 473 and 484-6, quoting Klotzsch.

36 A. Zucchiatti et al., "The 'della Robbia blue': a case study for the use of cobalt blue pigments in ceramics during the Italian renaissance," Archaeometry, 48 (2006), 131-52.

37 G. Bandini, Pietro Moioli, R. Scafè, and Claudio Seccaroni, "Studio sulle decorazioni policrome mediante fluorescenza $\mathrm{x}$ di alcune maioliche rinascimentali ritrovate in Roma," Faenza, 83 (1997), 223-51.

38 Zucchiatti et al., "The della Robbia Blue," 150. 
for the raw material for blue glazes in the Iberian peninsula was a new product, presumably also from mines near Schneeberg. ${ }^{39}$

The change in composition of cobalt blue glazes that occurred around 15171540 coincided with the commodification of zaffre on a very large scale throughout Europe. It is also at this moment that many artists began to use smalt in their works as a replacement for ultramarine and azurite. One reason to choose smalt over ultramarine was cost. In the majority of the early occurrences, smalt was used as a glaze over azurite, the way ultramarine was employed, which suggests that artists were using it as a substitute for ultramarine due to its similar color. The Italian artist Girolamo Romanino (ca. 1485-ca. 1566) must have been choosing smalt for its color when he layered it over azurite in The Nativity, around $1524 .{ }^{40}$ Successful painters, such as Nicholas Hilliard (ca. 1547-1619), who could afford it, often preferred ultramarine. But for Hilliard, price alone was not the determinant: Leonhard's discussion of his approach to color offers many hints to his pigment choices; for gems Hilliard favored pureness of color, hardness and transparency, the qualities of the best grades of ultramarine. ${ }^{41}$ However, other painters admitted a special role for smalt on the palette, for example, Edward Norgate (1581-1650) saying, "work your Blewish Skies and Cloudes with Smalt, not with Bise [azurite], for it is too Greene and Blewe."42 Richard Symonds who chronicled the work of artists while he travelled in Italy $\left(165^{-}-51\right)$ noted some painters' use of smalt thus: "Aria in Quadri Grandi. For it in great vast quadros in oyle, lo smalto is excellent wch is blew bice, \& so it has been usd at Venice where the ayre is seene at distance." 43

39 J. Pérez-Arantegui et al., "Materials and Technological Evolution of Ancient Cobalt-bluedecorated Ceramics: Pigments and Work Patterns in Tin-glazed Pbjects from Aragon (Spain) from the $15^{\text {th }}$ to the 18 th Century AD," Journal of the European Ceramic Society, 29 (2009), 2499-2509.

Marika Spring, Catherine Higgitt and David Saunders, "Investigation of Pigment-Medium Interaction in Oil Paint Containing Degraded Smalt," National Gallery Technical Bulletin, 26 (2005), 56-70.

Karin Leonhard, this volume

42 Edward Norgate, Miniatura, or, The Art of Limning, eds. Jeffrey M. Muller and Jim Murrell (New Haven, 1997). Despite this endorsement, smalt of a good color was too coarse to be particularly appropriate for miniature painting, nonetheless, a patent allowing manufacture of smalt in England made it prominent on the English palette after 1605. See Norgate, Miniatura, 122; Nicola Costaras, "Early Modern Blues: The Smalt Patent in Context," in Trade in Artists' Materials, 401-14.

43 Mary Beal, A Study of Richard Symonds. His Italian Notebooks and Their Relevance to Seventeenth-Century Painting Techniques (New York and London, 1984), 229-30. 
The intensity of color of the pigment was related to the amount of cobalt and also to the particle size. ${ }^{44}$ Early inventories noted only either smalto claro (chiaro) or smalto scuro (light or dark smalt); later, ways of grading smalt according to the depth of hue and an assessment of how finely it had been ground indicate the wide variation in the pigment quality. ${ }^{45}$ The coarsest smalt was the deepest colored, and prized for that, but no smalts were easy to use. They made a paint that was difficult to spread under the brush, and oil dulled the color, an effect most pronounced for the smalt with the largest particles. For this reason, artists developed a way to use smalt that did not rely on making a traditional paint. To preserve the deep and luminous color of the sparkling smalt they painted a thick layer of lead white onto a surface, and before it was dry they sprinkled the coarse particles of smalt over it, giving a highly colored, glittering surface. This practice was reflected in the name given to this grade of the pigment, "strew blue" or "streu blau." ${ }^{46}$ Varnishing smalt could cause the same kind of sinking in of the color, and this must be why the artist Giovanni Angelo Canini (1609-1666) told Symonds that blues ought never be varnished. ${ }^{47}$

Beckmann's assertion that the Dutch appreciated the invention of zaffre is borne out by their constructing many glasshouses by the late sixteenth century. ${ }^{48}$ It was estimated that 3,00o tons of zaffre were exported from Schneeberg, much of it going to Holland; Schürer sold it at seven and a half thalers a hundredweight. In the first half of the sixteenth century smalt was sold in Holland for fifty or sixty guilders. ${ }^{49}$ Blue tiles and Delftware dominated the aesthetic of

44 As noted by Roos in this volume, Hooke commented on this effect.

45 J.R.D. Riffault, A.D. Vergaund, and G.A. Toussant, A Practical Treatise on the Manufacture of Colors for Painting, rev. and ed. M.F. Malepeyre, trans. A.A. Fesquet (Philadelphia, 1874), $351-4$.

46 Turquet de Mayerne (1620) described this practice for all the blue pigments (Faidutti and Versini, 1974), 150. An early use of the term is in J.C. Lochner, Der künstliche Gold- und Silber-Arbeiter (Nuremberg, 1708), 123.

47 Beal, A Study of Richard Symonds, 250. The same effect is also true for large-particled azurite which loses its brilliance when varnished.

48 Beckmann, Inventions, 484.

49 These prices are often mentioned in the literature, but no firm evidence is given. However, the point is that zaffre and smalt were not especially expensive commodities in the color world (particularly in comparison to ultramarine). Price lists for smalt confirm it was a low to middle-priced pigment. See: Richard Spear, "A Century of Pigment Prices: Seventeenth-Century Italy," in Trade in Artists' Materials, 275-93. 


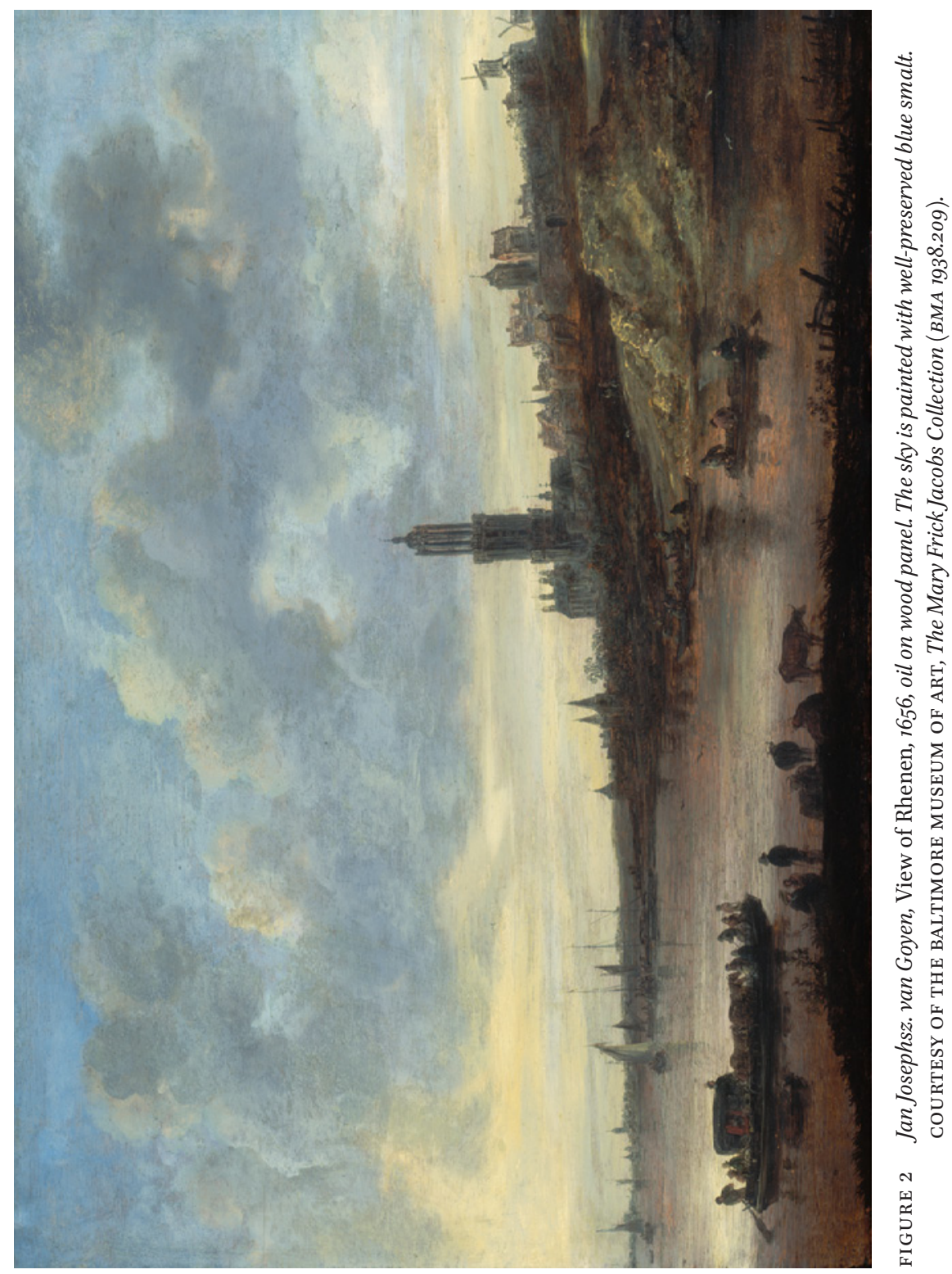


Dutch potters. Dutch smalt became broadly exported ${ }^{50}$ and some sorts were highly regarded. ${ }^{51}$

Many Dutch painters too enjoyed that blue color (Fig. 2). Rembrandt van Rijn (1606-1669) hardly used ultramarine, and azurite is found mainly in his earlier paintings in underlayers. Comprehensive studies have shown that smalt was the artist's choice. ${ }^{52}$ Smalt was used extensively in Spain during the seventeenth century. The product from one manufacturer in Holland, "Master Bernard," was much preferred and artists were willing to pay more for it because of its color. ${ }^{53}$ This information indicates the variability possible in making the colorant and artists' desire for specific qualities, as well as to how the Dutch mediated transfer of the material. The Spaniards began to re-export smalt (of various sorts, it seems) quite early on to the New World, as the words "esmaltes para pintores" on a bill of lading from 1592 attest. ${ }^{54}$

Although smalt is a glass, it is not particularly stable, since its formula does not contain stabilizing ions such as calcium, lead or barium. Our appreciation of the wide range of uses of smalt is hindered by its having deteriorated over time. The skies in paintings by the Venetian artist Paolo Veronese have turned greyish. ${ }^{55}$ The blue robe worn by the Virgin in Tintoretto's Madonna of the Stars has lost its blue color and become brownish. ${ }^{56}$ Unfortunately, the smalt Rembrandt used has decayed and the paint has become a turbid brownish color;

5o The Dutch supplied Ireland too. G.R. Mickle, "The Early History of the Cobalt Industry on Saxony," Report of the Bureau of Mines, Ontario Department of Mines, 16 (4) Appendix II, (1908) 182-98.

Zahira Véliz, "In Quest of a Useful Blue in Early Modern Spain," in Trade in Artists' Materials (2010), 389-400. See also Rocío Bruquetas Galán, Técnicas y materiales de la pintura española en los Siglos de Oro (Madrid, 2002).

Smalt is the major blue pigment on Rembrandt's paintings, but he also used vivianite, which might have had a local source. David Bomford et al., Art in the Making: Rembrandt (London, 2006), 45-7; TheRembrandtDatabase. Research resource on Rembrandt paintings, accessed January 18, 2015, <http://www.rembrandtdatabase.org/Rembrandt >. Véliz, "In Quest of a Useful Blue," 389-400.

54 José María Sánchez and María Dolores Quiñones, "Materiales pictóricos enviados a América en el siglo XVI," Anales del Instituto de Investigaciones Estéticas, 95 (2009), 45-67. Nicholas Penny and Marika Spring, "Veronese's Paintings in the National Gallery. Techniques and Materials: Part 1," National Gallery Technical Bulletin, 16 (1995), 4-30.

$5^{6}$ This was determined using X-ray fluorescence analysis. Kathryn Morales, April, 2015. A remnant of old blue, which provides only an imperfect hint of the original color, can be seen in a high-resolution image of the painting. See "The Madonna of the Stars," accessed July 2015, <http://www.nga.gov/content/ngaweb/Collection/art-object-page.33757.html>. 
backgrounds and curtains in his paintings are now dingy looking, but must once have been quite blue. ${ }^{57}$

Smalt and blue glass are chemically almost identical, differing in the proportion of cobalt. The glass was widely used for vessels, and in enamels and pottery glazes in the Middle Ages to provide a deep, true blue, but in contrast it was only sporadically used as a painter's pigment before 1500 ; however, it was used frequently in easel paintings from then on until the eighteenth century. ${ }^{58}$ The change in usage appears to be related to a change in the manufacturing process of the intermediate material zaffre used in the production of the color. This modification is suggested by a change in the profile of trace elements in blue glazes. Smalt was produced in large quantities and various grades which offered a handy and affordable alternative to ultramarine. It was ubiquitous by the beginning of the seventeenth century, occurring in paintings and architectural finishes, where it was even used for painting fictive lapis lazuli (Fig. 3).59 Smalt provided the desirable color of natural ultramarine at a fraction of the cost, and despite its difficult handling properties was widely adopted in the sixteenth century.

\section{Yellow and Orange}

Orange paint was conveniently made by mixing red and yellow pigments, though the color is not commonly seen before the sixteenth century. Red lead (minium) has a hot orange-red color and the arsenical sulfides orpiment and realgar provided deep yellow and reddish-orange colors. They were highly unpleasant to use - being both toxic and foul smelling when ground. Despite these disadvantages, regarding the famed color of the cinquecento Venetian artists, Lomazzo declared that "burnt orpiment is the alchemy of the Venetians," and indeed a warm orange color is a hallmark of their painting. ${ }^{60}$ Lead

57 Petria Noble and Annelies van Loon, "Rembrandt's Simeon's Song of Praise, 1631: Pictorial Devices in the Service of Illusion and Changes in Appearance," Art Matters. 4 (2007), 19-36.

$5^{8}$ Smalt has been found in many wall paintings and frescoes from the last quarter of the fifteenth century though these have been analyzed less than altarpieces and easel paintings. Claudio Seccaroni, personal communication, 11 April, 2015.

59 Smalt and gold were used to paint the columns of Great Yarmouth Chapel to imitate lapis lazuli. See: <http://www.greatyarmouthpreservationaltrust.org/en/news/2012/03/11/ st-georges-chapel $>$, accessed July 2015.

60 " "...] il ranzato le fà il minio, \& ancora l'oropimento arso, il quale si dice color d'oro. E questo è l'alchimia de i pittori Venetiani." Giovanni Paolo Lomazzo, Trattato dell'arte della pittura (Milan, 1584, reprinted 1965), 191. 


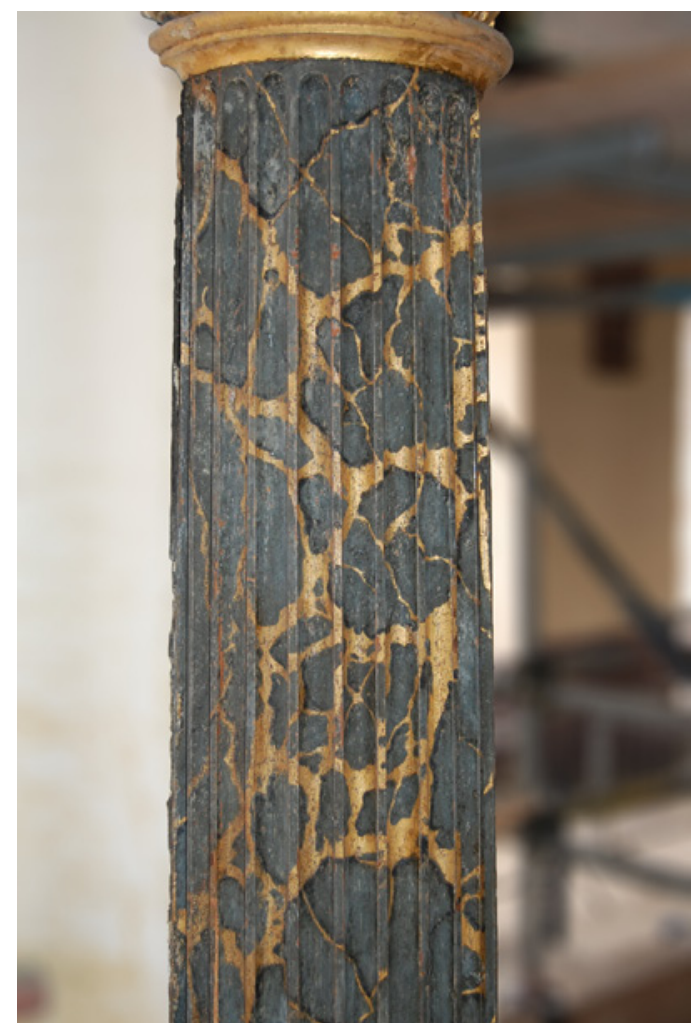

\section{FIGURE 3}

The grand columns in St. George's Chapel, Great Yarmouth, England (1714), painted using smalt and gold to simulate lapis lazuli.

COURTESY OF DARREN J. BARKER.

tin yellow was a reliable and clear-toned pigment, but the addition of antimony to the recipes offered a wide choice of deeper-hued pigments which filled a gap in the artists' palette.

\section{Antimony, Naples Yellow and Lead Tin Antimony Yellow}

Antimony had been used as an opacifier and to make yellow glass in Ancient Egypt and has been found in pottery glazes from as far back as 1300 BCE. ${ }^{61}$ It was used in Roman times until the fourth century CE when either major sources became unavailable or the art of working antimony up to make a colorant was forgotten, and manufacturing of lead antimony oxides was not under-

$61 \quad$ Ian N.M. Wainwright, John M. Taylor and Rosamond Harley, "Lead Antimonate Yellow," in Artists' Pigments: A Handbook of their History and Characteristics, ed. Robert L. Feller (Washington, D.C., 1984, reprinted 2012), 1: 219-354. 
taken to any significant degree during the next millenium. ${ }^{62}$ At the beginning of the seventeenth century, the pigment Naples yellow, lead antimony oxide, can be found in painters' works. ${ }^{63}$ Earlier than that, however, ceramic painters employed a glassy version of the colorant for their craft. Around 1485 a fundamental change in the technology and aesthetics of ceramic decorating occurred, allowing the development of intricately painted istoriato pottery. ${ }^{64}$ Due to the development of new enamels that fused but did not melt and flow in the kiln, artists could paint crisp, detailed compositions on white-glazed ware. A low-temperature melting glaze called a coperta could be sprinkled on the painted image and the object then fired only once to give a piece with a detailed image with a glossy surface. Low-flow white, yellow, orange and black colors contributed to the development of the new art form. ${ }^{65}$ Vibrant yellows and oranges often dominated the pictorial designs, but their source was not arsenic (Fig. 4). The white, yellow and orange pigments are glassy frits, enamels, or glasses opaquely colored by submillimeter crystallites of binary and ternary oxides of lead, tin and/or antimony suspended in lead - and calcium - rich siliceous matrices.

Cipriano Piccolpasso (1524-1579) noted these yellows in a compendium of recipes used in Gubbio, Castel Durante, Siena and Deruta, which he assembled in the middle of the sixteenth century. ${ }^{66} \mathrm{He}$ recorded recipes used in central Italy that included antimony for making yellow and green glazes. ${ }^{67}$ The lively palette of yellows and oranges on maiolica demonstrates the broad range of intense yellow hues that could be produced by adjusting the proportions of tin, antimony, iron and zinc in recipes. ${ }^{68}$ In essence, the maiolica decorators used

$62 \quad$ A silver-antimony ore was used by the Romans, see Jennifer L. Maas, Richard E. Stone and Mark T. Wypyski, "An Investigation of the Antimony-Containing Minerals used by the Romans to Prepare Opaque Colored Glasses," in Materials Issues in Art and Archaeology V, eds. Pamela B. Vandiver, James R. Druzik, John F. Merkel, John Stewart (Pittsburgh, 1997), 193-204.

63 Wainwright, "Lead Antimonate Yellow," 221-4.

64 W. David Kingery, "Painterly Maiolica of the Italian Renaissance," Technology and Culture, 34 (1993), 28-48.

65 Ibid., 37 .

66 Cipriano Piccolpasso, The Three Books of the Potter's Art, 2 vols., trans. and eds. Ronald Lightbown and Alan Caiger-Smith (London, 1980).

67 Ibid., 1: 55/66, 1: 56/67-68, 1: 81/132-133.

68 C. Sandalinas et al., "Experimental Confirmation by Raman Spectroscopy of a Pb-Sn-Sb Triple Oxide Yellow Pigment in Sixteenth-century Italian Pottery," Journal of Raman Spectroscopy, 37 (2006), 1146-1153. Further variety can be introduced by changing the temperature of the kiln, see Joris Dik et al., "Early Production Recipes for Lead Antimonate Yellow in Italian Art," Archeometry, 47 (2005), 593-6o7. 


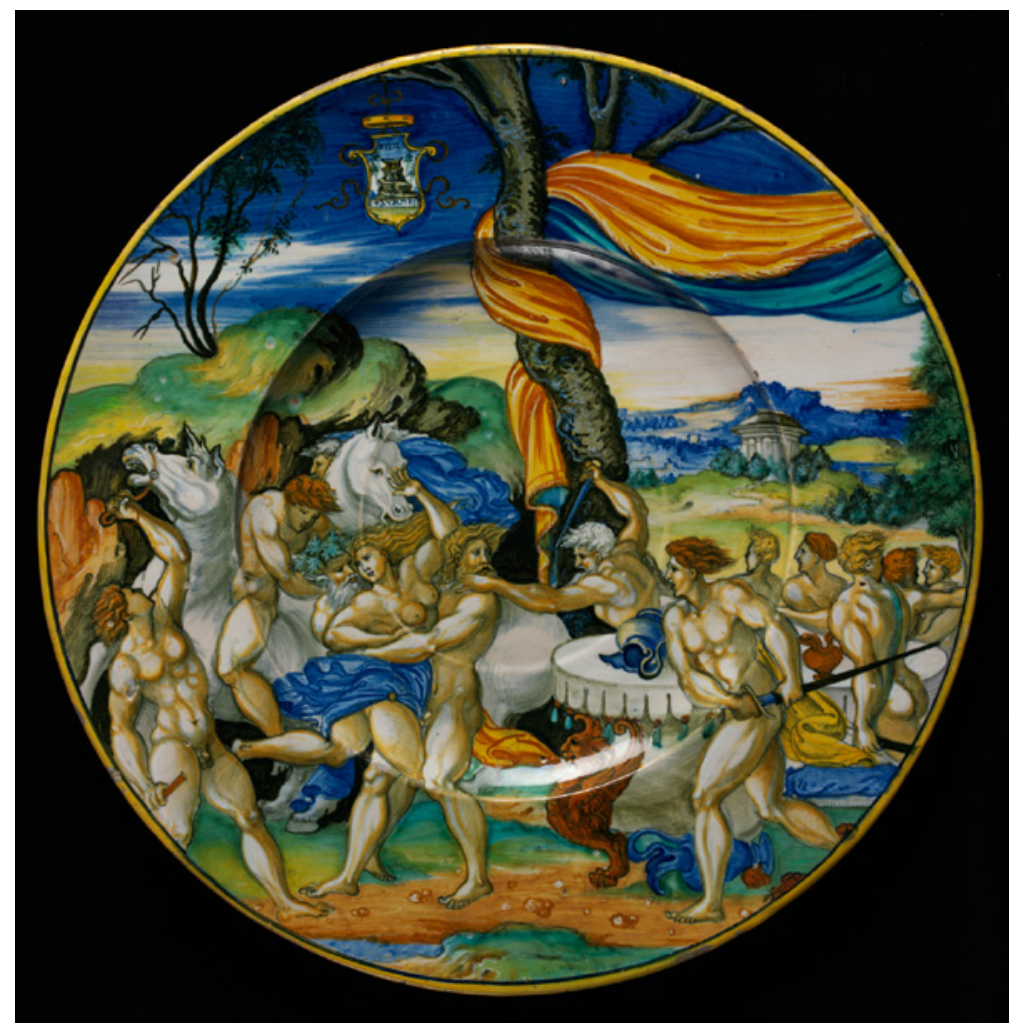

FIGURE 4 Nicola da Urbino, an istoriato maiolica dish, 1535-1538. Victoria and Albert Museum (c. 2246-1910). Bequeathed by George Salting, Esq. (c) VICTORIA AND ALBERT MUSEUM, LONDON.

colors in the same way as easel painters used their paints. ${ }^{69}$ What is interesting about these pigments is that they did not change color in the furnace, so tonal work as well as fineness of line survived the firing process. ${ }^{70}$ These recipes for yellow pigments are the first to use antimony that we know of in the early

69 The designs were painted after drawings using fine brushes in a painterly manner. 'Art' and 'craft' were linked since easel painters sometimes provided designs for istoriato ware. For example, Dosso Dossi, a court painter for Alfonso I d'Este, Duke of Ferrara, was paid for designs for plates. Giuseppe Campori, "Notizie storiche e artistiche della maiolica e della porcellana di Ferrara nei secoli vv e XVI," in Istorie delle Fabriche di Majoliche Metuarensi, ed. Giuliano Vanzolini, vol 2, (Pesaro, 1879), 127. Alfonso asked Titian to oversee production of large jars in Venice. See: Timothy Wilson, "Maiolica in Renaissance Venice," Apollo, 125 (1987), 184-9, esp. 185.

70 Steve Wharton, "What you See is What You Get: Colour in Italian Renaissance Istoriato Ware," Renaissance Studies, 19 (2005), 592-603. 
modern period. Biringuccio stated that there were several antimony mines in the vicinity of Siena, Maremma and Santa Fiora in Tuscany. ${ }^{71}$ Piccolpasso made the same assertion. ${ }^{72}$ These mines had likely been exploited for centuries, but the product must not have been preferred or was difficult to use or purify. Biringuccio noted that antimony was sourced from the north of the country. ${ }^{73}$ Piccolpasso said the best antimony was obtained in Venice where it was imported from Germany. ${ }^{74}$ Antimony was used in metal type to give crisp letters and it has been suggested that antimony recycled from old type was reused for many purposes. ${ }^{75}$ The superiority of the antimony from the north might have been the catalyst for the development of the industry in Italy.

The lead-based yellow pigments used in easel painting, generally called giallolino or giallorino in Italian, masticot in English, or lithargyrum in Latin and plygel (from blei meaning 'lead' and gelb meaning 'yellow') in German sources, form a group of colors prepared in the kiln. ${ }^{76}$ Lead oxides (massicot and litharge), lead-tin oxides, lead-antimony oxides and lead-tin-antimony oxides have all been found in paintings dating from the early sixteenth century onward. ${ }^{77}$ Color names that are still being studied suggest sources and production methods for the pigments. ${ }^{78}$ The history of these pigments is not continuous, stopping and restarting with variations over time, and indeed they intermix at points. The reasons for the substitutions are not well known, but involve changes in sources for raw materials, whether due to local discoveries

71 Biringuccio, Pirotechnia, 90-1.

72 He may have been quoting Biringuccio. See Lightbown and Caiger-Smith: Piccolpasso, The Three Books, 2: 66.

73 When Biringuccio spoke of "antimonio," he was describing antimony sulphide while metallic antimony was "regolo de antimonio."

74 Antimony ores are dispersed throughout Germany, Hungary, and Austria. In Italy, there are also sources for the materials in Tuscany and Sardinia. See Chung Yu Wang, Antimony (London, 1919), 47-53.

75 Hermann Kühn et al., Reclams Handbuch der künstlerischen Techniken, 3 vols. (Stuttgart, 1984), I, 364, 366. Isotope ratios for the lead used in Naples yellow in have been interpreted as showing that Turkey was the source for the lead used to make the colorant found in fifteenth and sixteenth century mailolica and perhaps was the source for the recipe as well, see: Laura Chiarantini et al., "Early Renaissance Production Recipes for Naples Yellow Pigment: A Mineralogical and Lead Isotope Study of Italian Majolica from Montelupo (Florence)," Archeometry, 57 (2015), 879-96.

76 Claudio Seccaroni, Giallorino: Storia dei pigmenti gialli di natura sintetica (Rome, 2006).

77 Wainwright et al., "Lead Antimonate Yellow," 225-6.

78 Seccaroni, Giallorino, 93-165. These names might refer to lead tin yellow, lead antimony yellow or lead tin antimony yellow since the manufacture was so variable. They include "giallo di Fiandra," "giallo in vetro," "giallo di fornace," "giallo di Alemania," etc. 
of ore or the disruption of trade. Lead tin oxide, free from any silicon, had been the predominant light yellow augmenting the range of hue obtained from yellow iron earths. ${ }^{79}$ Shortly after 1500 , rich deep yellows based on siliceous oxides of antimony, lead, tin and/or antimony reappear on painters' palettes in very small amounts, only a few years after their prolific use on pottery began.

Analysis of yellow pigments in paintings has revealed the re-emergence of the use of yellow lead-tin glasses (lead tin yellow type II) for easel painting occurred in Venice in the mid-1500s. ${ }^{80}$ But before then, a few artists had already borrowed colors from the potters. The materials would have been hard to grind, but the variety of colors must have been alluring. The painter Lorenzo Lotto (ca. 1480-1556/7) kept a ledger of his expenses related to his art making, and this included pigments he purchased. One that has been of great interest is "zalolin da vasari" which he bought at Venice in $1541 .{ }^{81}$ Since Piccolpasso gave many recipes for yellow glazes, we cannot be sure of the breadth of colors available at the color-seller's shop; ${ }^{82}$ but we do know from analysis that Lotto used a small portion of a siliceous lead-antimony compound in the amber yellow robe worn by Joseph in his painting, The Nativity, which is dated to 1523 (Fig. 5) ${ }^{83}$ Seccaroni gives some other examples of antimonial yellows in early cinquecento paintings and frescoes. ${ }^{84}$

The Venetian painter Giovanni Bellini (ca. 1430-1516) had a long career that spanned the change in painting in tempera to painting in oil. Analysis of his methods and materials offers a vivid example of an artist changing and adapting. He was among the first Italians we know of to use smalt in oil paint-

79 Hermann Kühn, "Lead-Tin Yellow," in Artists' Pigments: A Handbook of the History and Characteristics, (Washington, D.C., 1993, reprinted 2012), 2: 83-112.

80 Corenelia Syre, Andreas Burmester and Christoph Kreckel, "Sprezzatura" in Tintoretto: The Gonzaga Cycle, exhibition catalogue, (Munich, 2000), 196-7.

$81 \quad$ Lorenzo Lotto, Libro Di Spese Diverse, 2 vols., eds. Floriano Grimaldi and Katy Sordi (Loreto, 2003). See also Paolo Bensi, Studi di storia dell'arte, 5 (1983-1985), 63.

82 Symonds noted that the Roman painter Canini (1609-1666) used three or four different kinds of 'giallo lino'. See Beal, A Study of Richard Symonds (1984), $25^{2}$.

83 Barbara H. Berrie and Louisa C. Matthew, "New Materials on the Renaissance Artists' Palette," 7th Symposium on Materials Issues in Art and Archaeology, eds. Pamela Vandiver, Jennifer Mass and Alison Murray (Warrenton, 2005), 131-40. He also used an antimonycontaining pigment in 'Portrait of Giovanni della Volta and his Family (?)', probably 1547; see Ashok Roy and Barbara Berrie, "A New Lead-Based Yellow in the Seventeenth Century," in Painting Techniques: History, Materials and Studio Practice, Contributions to the Dublin Congress of the IIC, eds. Ashok Roy and Perry Smith (London, 1998), 160-5.

84 Seccaroni, Giallorino, $153-65$. 


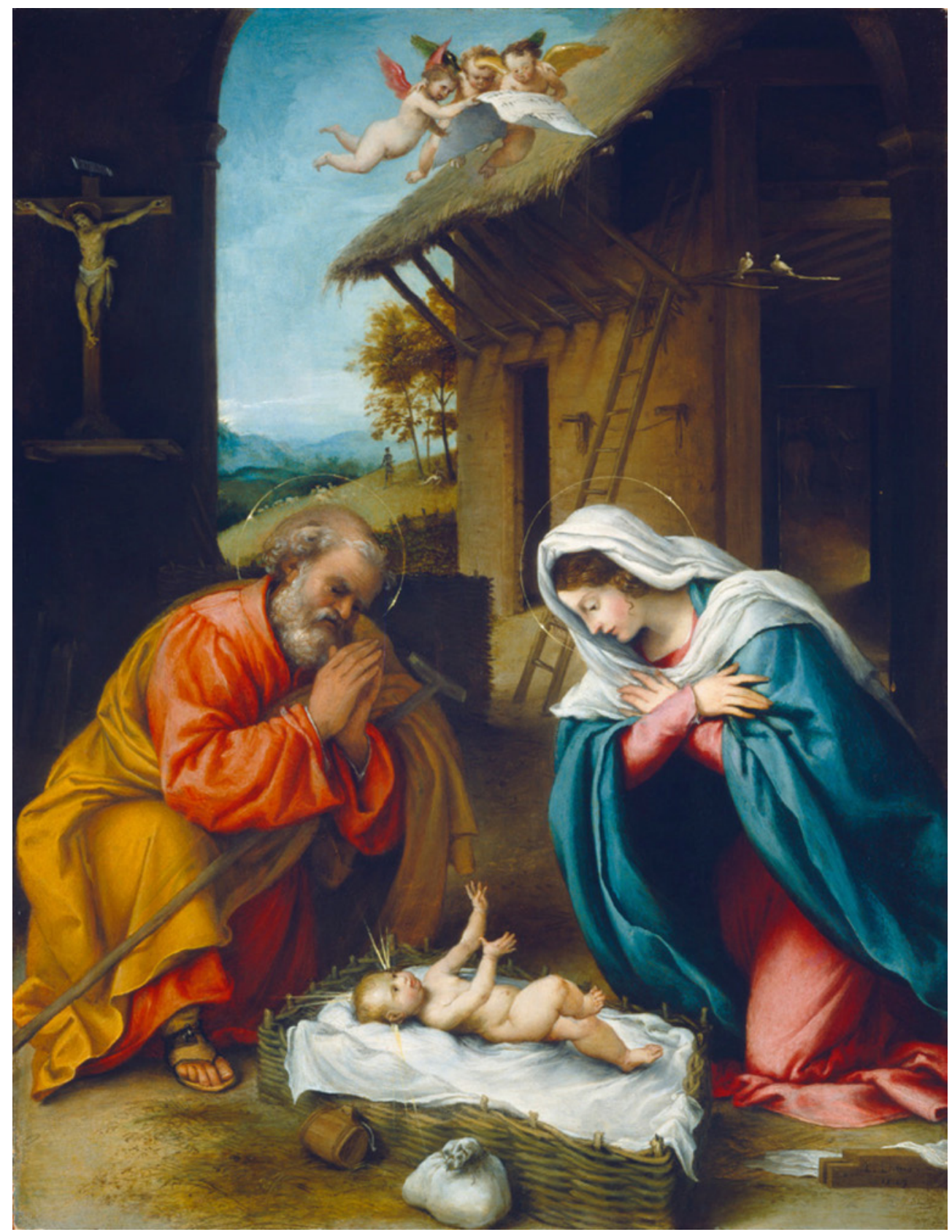

FIGURE 5 Lorenzo Lotto, The Nativity, 1523, oil on panel. Joseph's deep yellow robe contains a glassy antimony yellow which could be the zalolin da vasari mentioned in his account books. COURTESY OF NGA, SAMUEL H. KRESS COLLECTION (1939.1.117). 


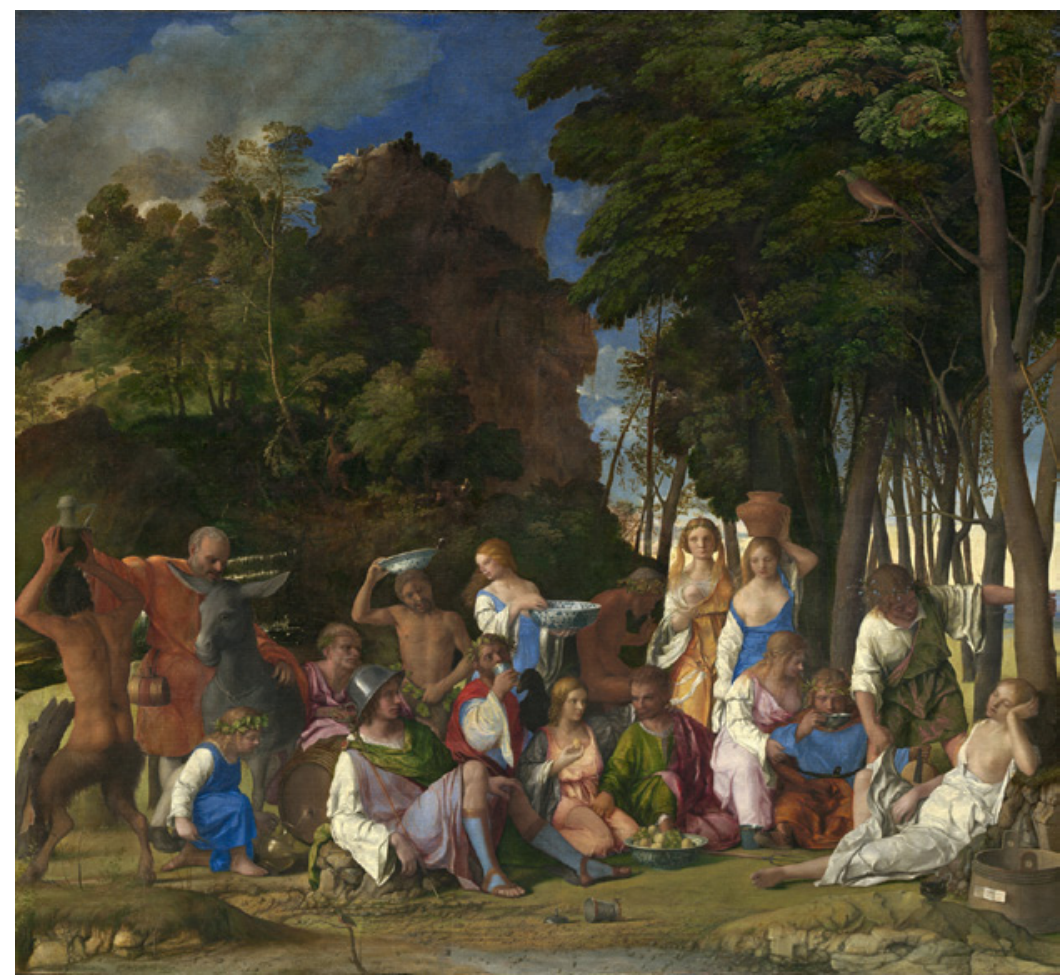

FIGURE 6 Giovanni Bellini and Titian, The Feast of the Gods, 1514/1529, oil on canvas. Bellini added a glassy antimony yellow to azurite in the paint along the horizon to subtly change its hue. COURTESY OF NGA, WIDENER COLLECTION (1942.9.1).

ing. ${ }^{85}$ In a further exploration of the materiality of color, he added a very small proportion of opaque antimony orange glass to blue azurite for painting the horizon in Feast of the Gods. ${ }^{86}$ He completed this work in 1514 (Fig. 6). ${ }^{87}$ This is

85 Gianluca Poldi, "Note quasi sparse sul colore e la tecnica di Giambellino. Nuovi studi analitici," in Indagando Bellini, eds. Gianluca Poldi and Giovanni Carlo Federico Villa (Milan, 2009), 161-70.

86 Barbara H. Berrie and Louisa C. Matthew, "Venetian 'Colore:' Artists at the Intersection of Technology and History," in Bellini, Giorgione, Titian and the Renaissance of Venetian Painting, exhibition catalogue, eds. David Alan Brown and Sylvia Ferino-Pagden (Washington, D.C. and Vienna, 2006), 301-9.

87 Bellini finished the painting in Venice and it was sent to Alfonso I at the Este court in Ferrara. In 1523 Titian painted other works for Alfonso and reworked Bellini's Feast of the Gods. David Bull and Joyce Plesters, The Feast of the Gods: Conservation, Examination, and Interpretation (Washington, D.C., 1990). 
a remarkable use of mixing complementary colors to adjust hue. ${ }^{88}$ It is innovative, rare and indicative of Bellini's sensitivity to color. There was no stable orange on the traditional, typical palette that could have been safely used in combination with the copper carbonate mineral azurite. Perhaps a dye could have offered an orange-yellow, but such dyes fade rapidly. Realgar and orpiment, which Bellini used in this picture to paint Silenus' orange tunic, were known to react with the copper compounds. ${ }^{89}$ Red lead was known to darken in certain mixtures. ${ }^{90}$ The pigment Bellini decided on is a siliceous material and certainly related to the colors for decorating glass and ceramics. Bellini's and Lotto's antimonial yellows are not the classic Naples yellow of later times, but early uses of "potter's yellow," of which there were many variants, for painting in oil. 91

The bright and deep-hued yellows that we find in paintings from this time were not invented for the 'figurer' or easel painter; they were for the artisans who decorated ceramics and for glass-makers who used concentrated colors to make stained glass and false gems. The amount of material used by potters was considerable, but the adoption of the yellow to the artists' palette was slow in comparison. Sometime in the early seventeenth century, the nature of the antimony-containing product changed and the glassy constituent was not present. This indicates another moment in the development of the color, but its invention is unknown, though Wainwright et al. wondered if it occurred in Naples. ${ }^{92}$

88 Berrie and Matthew, "Venetian 'Colore," 305.

89 Most often indigo is mixed with orpiment to give green colors, since orpiment reacts with copper minerals. In particular, its incompatibility with verdigris had been noted for a long time. See Daniel V. Thompson, The Materials and Techniques of Medieval Painting (1936, reprinted 1956), 169 .

9o Cennini commented that red lead turned black when used on walls, as did vermilion. Daniel V. Thompson, The Craftsman's Handbook “Il Libro dell'Arte (New York, 1960), 24-25. The author of the Mappae Clavicula warned of the incompatibility of red lead and orpiment, see Cyril Stanley Smith and John G. Hawthorne, "Mappae Clavicula: A Little Key to the World of Medieval Techniques," Transactions of the American Philosophical Society, 64 (4) (1974), 1-128.

91 Joris Dik et al., "Early Production Recipes for Lead Antimonate Yellow in Italian Art," Archeometry, 47 (2005), 593-607; Claudia Pelosi et al., "Artificial Yellow Pigments: Production and Characterization through Spectroscopic Methods of Analysis," ePreservationScience, 7 (2010), 108-15; Laura Cartechini et al., "Modified Naples Yellow in Renaissance Majolica: Study of Pb-Sb-Zn and Pb-Sb-Fe Ternary Pyroantimonates by X-ray Absorption Spectroscopy," Journal of Analytical Atomic Spectroscopy, 26 (2011), 2500-7.

Wainwright et al., "Lead Antimonate Yellow," 230-1. 


\section{Fluid, Transparent Paint}

For all the nuance of hue and shade that was possible using the augmented sixteenth-century palette, an artist's skill and sensitivity to mixing, juxtaposing and layering paint were nonetheless required for mimetic effects. As Paolo Pino (1534-1565) noted, writing about painting and the role of color in creating realistic and lively works, the ineffable quality of colors such as ultramarine and lakes do not only show their beauty when giving art its zest, since these colors are already beautiful in their boxes. ${ }^{93}$ One way that artists worked up color for painting was to use multiple thin, translucent layers that mix color in luminous, vibrant ways. Lomazzo described, if only briefly, how to paint "transparently."94 This mode of color mixing relies on being able to paint translucently, smoothly and thinly. Our ability to understand how early modern artists achieved this is hindered by the essential fact that we cannot know from an analytical perspective about the ways they thinned their paint since most of the diluent is, by necessity, volatile. ${ }^{95}$ The early Netherlandish artists somehow used oil to great effect in a way unknown to the Italians.

Vasari, writing in The Life of Antonello da Messina (1430-1479) who was believed to have brought the secret of painting in oil to Italians said,

But when he [Johann of Bruges, or Jan van Eyck] became old he finally bestowed the favour upon Ruggieri da Bruggia, his pupil, and Ruggieri told Ausse his student and others who are mentioned in works treating the subject of oil painting. But in spite of this [...] the method did not travel beyond Flanders. And although such works, especially when they were fresh and when it seemed possible to recognize the secret, possessed the sharp odour that the colours and the oils mixed together gave them, this secret was still never discovered over the course of many years. ${ }^{96}$

Since pure linseed oil has a quite subtle smell, the mention of odor alerts us to the addition of a solvent or diluent for the paint. The likely materials are

93 Paolo Pino, Dialogo della pittura (Venice, 1548), accessed February 2, 2015, <http://www. memofonte.it/home/files/pdf/scritti_pino, 15>.

94 Giovanni Paolo Lomazzo, Trattato dell'arte della pittura (Milan, 1584, reprinted 1965), 191.

95 Painters could have had access to alcohol and learned to use it, as has been discussed in Rachel Billinge et al., "Early Northern European Painting," National Gallery Technical Bulletin, 18 (1997), 41-2.

96 Giorgio Vasari, The Lives of the Artists, trans. Julia Conaway Bondanella and Peter Bondanella (Oxford, 1991), 187. 
distillates of balsams or turpentine or essential oils, which are often mentioned in treatises on painting. Work-up of these involved collection, which depending on the source demanded tapping trees, or grinding seeds, followed by purification and refining, using filtration and distillation. ${ }^{97}$ Mineral oil or naphtha was also a possibility. Mineral oil appears on color-sellers' inventories, but we know relatively little about its uses in art and color making, though it is mentioned in sixteenth-century guides for painters. ${ }^{98}$ One of many examples is a recipe for "varnish that dries in the sun" in Borghini's Il Riposo:

That which is dried in the sun can be made [in] two ways. In the first, taking an ounce of pine oil and an ounce of petroleum oil and mixing them together, this is heated and when lukewarm is used by spreading thinly. In the other way, two ounces of walnut oil, an ounce of mastic, and a half ounce of petroleum oil are taken and mixed together and put to the fire. ${ }^{99}$

Italy and Austria had documented sources of mineral oil. ${ }^{100}$ Gerali has suggested that before oil became an industrial or commercial commodity in the mid-nineteenth century it was mined locally and not transported, and discovered, not sought out. It appeared in caverns, caves and on lakes mixed with water. ${ }^{101}$ The rarity of very pure oozing oil contributed to its value for medicinal purposes, another example of the very purest sort of a material used in the color trade being reserved for medicine. The surge of interest in medicine and medicinals in the sixteenth century was spurred by important developments in distillation. ${ }^{102}$ Strides in improving methods and apparatus for distillation

97 Merrifield has commented on the early literature of varnish making. See Mary P. Merrifield, Original Treatises on the Arts of Painting (New York, 1969).

98 "Olio di sasso" is listed on a 1534 inventory; Louisa C. Matthew, "Le vernis dans les boutiques des marchands de couleurs vénitiens," De la peinture de chevalet à l'instrument de musique: vernis, liants et couleurs, Musée de la musique, Paris, eds. Stéphane Vaiedelich and Jean-Philippe Echard (Paris, 2008), 22-5; and "oglio de saso" in a small quantity on a 1596 inventory of a color seller, see Roland Krishel, in Trade in Artists' Materials (London, 2010), 253-66.

Lloyd H. Ellis, Raffaello Borghini's Il Riposo': A Critical Study and Annotated Translation (PhD diss., Case Western University, Cleveland, 2002) 428-9.

$100 \quad$ Novelli and Sella, Petrolio.

101 Francesco Gerali, "The Development of the Italian Oil Industry in the Emilian Appenines," Oil-Industry History, 11 (2010), 173-86. Naphtha was most often found in conjunction with bitumen. The smell in mines was nauseating and miners could only stay in the shafts a short while.

Among the earliest books on distillation were Hieronymus Brunschwig, Liber de arte distillandi de simplicibus (Strasbourg, 1500) and Liber de arte distillandi de compositis 
also benefitted the lucrative perfume industry. ${ }^{103}$ The purification and production of light fractions of native mineral oil would also have helped artists who liked to spread their paints thinly. The innovative achievements of sixteenthand seventeenth-century artists is due not only to their expanded palette but also to their exploration of ways to handle paint. Many writers talk of blending colors, but the stiffness of some colors of oil paint would make this difficult. Lorenzo Lotto, who painted with thin glazing layers of red paint purchased materials for varnish making, including olio di sasso. ${ }^{104}$ We know from written descriptions and the evidence from fingerprints that artists of this time manipulated the paint with their fingers, and we can tell from the thinness of layers of oil paint that it must have been extended with a diluent. ${ }^{105}$ Spirits of turpentine, prepared by distilling resins, would have performed this service. Since mineral oil or naphtha is mentioned more frequently in texts and we know that efforts for mining it increased in the sixteenth and seventeenth centuries, we must assume artists used it as well.

(Strasbourg, 1512). Within decades these books were translated (English edition 1527) and new books written. In Venice many stills were set up in the mid-150os and by 1640 distillers became separately recognized tradesmen. See Richard Palmer, "Pharmacy in the Republic of Venice in the Sixteenth Century," The Medical Renaissance of the Sixteenth Century, eds. Andrew Wear, Roger Kenneth French and Iain M. Lonie (Cambridge, 1985), $100-17$.

103 On making perfumes, Woolgar has noted that most significant changes occurred in the sixteenth century: "[...] naphtha-water, a volatile mix of water and extract of bitumen [was used], but most medieval perfumery was based on oils perfumed by absorption." Advances were limited by the difficulties of distillation, although that did not prevent many in England producing infusions." C.M. Woolgar, The Senses in Late Medieval England (New Haven, 2006), 137.

104 Matthew, "Le Vernis," 22-5.

105 Giovanni Battista Armenini (1530-1609) in his treatise on painting described patting translucent paints (lakes, smalt and copper green) with the hand or using a wad to even them out, as noted in Renate Woodhuysen-Keller, "Aspects of painting technique in the use of verdigris and copper resinate," in Historical Painting Techniques, Materials and Studio Practice, eds. Arie Wallert, Erma Hermens and Marja Peek (Marina del Ray, 1995), 65-9. Titian's mixing paint with his fingers was described by Giacomo Palma the Younger to Boschini, see Joy A. Thornton, Renaissance Color Theory and Some Paintings by Veronese (PhD diss., University of Pittsburg, 1979) 196-7. 


\section{Conclusion}

Our understanding of the material world of color is founded on many sources including descriptions by artists themselves, merchants, treatises and commentaries. Each of these provides a single perspective, oftentimes individual and subjective. Adding chemical analysis of the colorants actually used in paintings helps to round out the picture and provide a concrete time for their use. From this type of analysis, we find that the adoption of smalt and Naples yellow for easel painting follow similar stories. When mining and technological circumstances increased the availability - or felicitously altered the formulation - of the colorants in the early sixteenth century they became more widely used. These pigments, adopted from the arts of glass-making and pottery decoration, were first used by a few artists in limited and specific ways, apparently related to a desire to achieve particular colors or effects. These innovators, using atypical materials that might have been refractory, in the sense of challenging to use, paved the path for those who followed them, and both smalt and Naples yellow found secure and prominent places on the artists' palette, enlivening the blue and yellow spectrum on paintings. When and how solvents were introduced to oil painting remains unclear, but in order to exploit the full possibility of infinite shading by using multiple translucent glazes and blending, thin layers of paint would be preferred. Fast-evaporating solvents such as naphtha, which was being increasingly mentioned in relation to artistic endeavors in the sixteenth century, would make this kind of work more facile. The thinness of paint glazes in pictures, especially red and green glazes, assures us that though written evidence for specific products that could thin paint is still scarce, some early modern artists must have been using distilled solvents to achieve their goals of mimesis. 